\title{
Seismic Vulnerability Assessment of Single-Story Masonry Buildings in Kurdistan Region - Iraq
}

\author{
Abdulhameed A. Yaseen ${ }^{1}$, Mezgeen S. Ahmed ${ }^{2}$ \\ College of Engineering, University of Duhok, Kurdistan Region - Iraq
}

\begin{abstract}
Although the Kurdistan Region (KR) of Iraq lies in a relatively active seismic zone, most of its buildings have not been designed to resist seismic loads. So, the need to assess the vulnerability of the building stock to damage due to seismic loads will always be a demand. The building environment in the KR had extensively utilized low-rise unreinforced masonry (URM) buildings having one- to two-stories. The single-story buildings constitute about $67 \%$ of the total buildings in the region. The study aims to assess these types of buildings (single-story URM buildings) using the analytical fragility analysis approach. For that purpose, buildings in the region were classified and a typical single-story URM building was analytically modelled in TREMURI software. Seismic characteristics of KR were reviewed and based on it, 59 un-scaled ground motion time histories were selected from all parts of the world. Using incremental dynamic analysis, time histories applied to the analytical model and fragility curves were then developed for the different states of damage. The results show that the single-story buildings in the region are highly susceptible to slight and moderate damages under seismic loads; extensive as well as the very heavy damage states are likewise expected to happen in these types of buildings especially in the eastern part of the KR.
\end{abstract}

KEYWORDS : Seismic Vulnerability, Fragility Curve, Unreinforced Masonry Building, Incremental Dynamic Analysis.

\section{INTRODUCTION}

Evidences show that earthquakes can cause significant disasters when they hit crowded areas in either rural or urban environments. $75 \%$ of casualties that are caused by earthquakes are because of the collapse of buildings (Coburn and Spence, 2002) and the unreinforced masonry buildings (URM) is the one presenting the greatest vulnerability (Grünthal, 1998). Over the last decade, researchers have aimed to develop reliable vulnerability assessment procedures to determine the safety of seismically deficient buildings and to evaluate retrofit or demolition alternatives. These vulnerability assessment methods are of great importance for preparing a proper management, awareness, improvement and recovery plan for reducing the

Academic Journal of Nawroz University

(AJNU) Volume 7, No 4 (2018).

Regular research paper : Published 8 December 2018

Corresponding author's e-mail :

Abdulhameed.yaseen@gmail.com

Copyright $@ 2017$ Abdulhameed A. Yaseen 1 ,

Mezgeen S. Ahmed².

This is an open access article distributed under the Creative earthquake vulnerability. Fragility analysis is one of those procedures can be effectively used for that purposes (Park et al., 2009). The fragility of a structure can be defined as its ability to resist the damage caused by an earthquake (damageability) and is usually used to represent the seismic vulnerability of a structure graphically in terms of fragility curves (Porter, 2003). These fragility curves show the probability of reaching or exceeding specific damage levels in terms of a seismic intensity measure. The present study aims to perform a seismic fragility analysis on single-story unreinforced masonry buildings in the KR of Iraq (Fig. 1) as most hazardous part in the whole of Iraq. The collapse of building structures during recent earthquakes, particularly in the countries around Kurdistan such as Turkey (the 2011 Van earthquake) and Iran (the 2017 Sarpol-e Zahab earthquake), has raised many questions about the safety of the existing buildings in the region and those structures that are going to be constructed in the future. Based on the availability of damage data, fragility curves can be derived using the following four methods: empirical (observed post-seismic statistics), analytical (lack of observed damage data), judgmental (expert judgment 
in both cases, availability or not availability of damage data), or hybrid (combinations of these three methods) techniques (Rossetto and Elnashai 2003; Calvi et al., 2006). In the absence of such kind of observed data (in a regions such as KR), analytical methods are often used to assess the vulnerability of structures and deriving fragility curves (Nielson and DesRoches, 2007). However, before any further step is taken towards the application of the methodology, it is of great importance to illuminate some important aspects that govern all analytical experiences in the field of fragility analysis. The choices made for the analysis method, structural idealization, seismic hazard characterization and damage models strongly influence the derived fragility curves and can cause significant discrepancies in seismic risk assessments made by different groups for the same location, structure type and seismicity. The basic components that are required to analytically derive fragility curves are shown in Fig. 2 and can be described through the following sections.

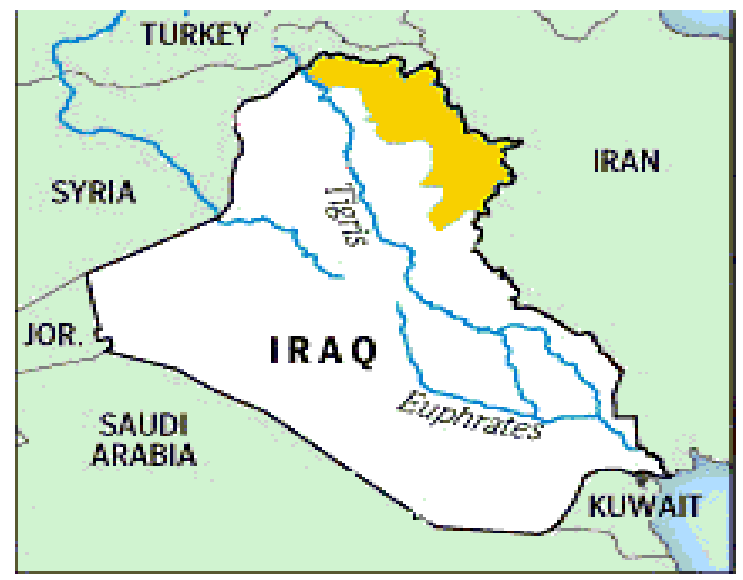

Kurdistan Regional Government boun

Fig (1) : Kurdistan Region of Iraq and its neighborhoods

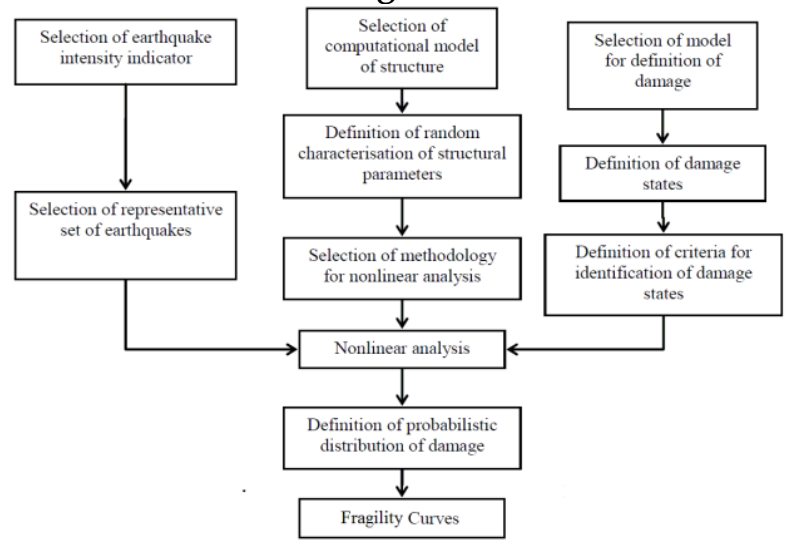

Fig (2) : The basic components that are required to analytically derive fragility curves (modified from Calvi et al., 2006)

\section{METHODOLOGY}

\subsection{Structural Idealization}

An essential first step towards estimating the earthquake failure probability of structures of any region is to prepare and develop an appropriate set of database on structural systems relevant to that area (Liao et al., 2006). An initial understanding of characteristics and morphology of the materials as well as weaknesses and vulnerabilities to the system is then achieved by identification of the structural typology using this database. These details along with other information such as the current and intended use of the structure, location of the structure and its surrounds nature provide a clear idea about the structure that is used for each later stage of the assessment. Exposure information for a region requires a standard systematic inventory system that classifies the structures according to their type, occupancy, and function so that realistic estimates of seismic risk and loss can be made (FEMA, 1999). Such an inventory data collection and classification system can be developed for the KR similar to the system used and reported in ATC-13 (ATC, 1985) and HAZUS (FEMA, 1999) as presented in Fig. 3. From Fig. 3 it can be seen that constructed facilities are categorized into four main systems, including: buildings and facilities, transportation systems, utility systems and hazardous material systems. Neglecting the three latter systems, the building and facilities system is considered here by focusing on general building stock. This classification will be essential for evaluating the damage level of a typical building considering a suitable limit state as a representative parameter for those damage levels. The relationship between ground-motion intensity measure ary the computed damage are then compared and finally the fragility curve will be proposed for the given class of structure.

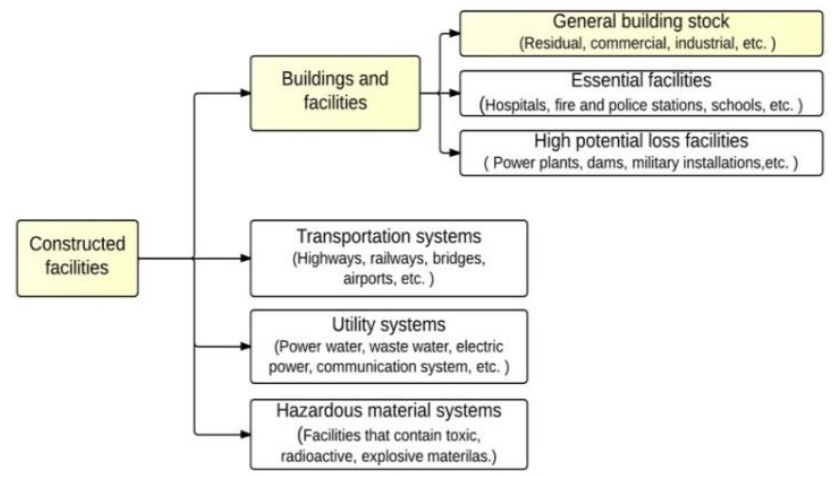

Fig (3) : A structural inventory classification system (ATC, 1985; FEMA, 1999)

Considering the aforementioned classification system and based on data available in the Central Statistical Organization CSO (2011), the building stock data 
relevant to Kurdistan can be summarized as follows: the majority of people (around 80\%) in the region lives in the buildings which have been widely scattered in the urban areas and constitute $77 \%$ of total buildings. $70 \%$ of the buildings is used for dwelling purposes versus $30 \%$ for other types of uses. Moreover, the statistics also show that $87 \%$ of the total buildings in the study area are 1 to 2 floors, and $13 \%$ are 3 or greater. The buildings with the number of floors less than 3 are mainly URM buildings represented by (URML) type of HAZUS-MH (FEMA, 2003) building classification model, while the buildings with 3 floors are dual system buildings represented by reinforced concrete frame on the base floor and URM floors at the top levels. Buildings with 4 (or greater) floors are reinforced concrete frame with URM Infill walls representing $(\mathrm{C} 3 \mathrm{M})$ and $(\mathrm{C} 3 \mathrm{H})$ type of HAZUS-MH (FEMA, 2003) building classification model. Although half of the buildings have been built after the Iraqi Seismic code 1997 (BRC, 1997), most of the buildings in the region were not designed to resist seismic loads. To this end, a typical URM building was selected to be modeled as representative of the singlestory buildings (see Fig. 4) which constitute about $67 \%$ of residential building stock in Kurdistan urban areas.

The building stock for residential purposes shows a variation from regular to irregular in horizontal and elevation plans. These buildings are mostly rectangular in plan with dimensions $7.5 \mathrm{~m} \times 20 \mathrm{~m}$ and $10 \mathrm{~m} \times 20 \mathrm{~m}$ including front yard. However, the majority of the URM buildings are of the size $10 \mathrm{~m} \times 20 \mathrm{~m}$ which will be $10 \mathrm{~m} \times$ $15 \mathrm{~m}$ excluding the front yard. The clear interstory height of a single story building is typically $3.0 \mathrm{~m}$. The ring beams are monolithic with the slab and the connection between walls and slab are achieved through cement and mortar. Most of the URM buildings have $15 \mathrm{~cm}$ R.C slab in the proportion 1:2:4 (cement: sand: gravel) mixed in a suitable amount of water. The wall thickness is $200 \mathrm{~mm}$ and the masonry units used in construction are solid concrete blocks with dimensions $400 \mathrm{~mm} \times 200 \mathrm{~mm} \times 150 \mathrm{~mm}$ which are constructed according to ASTM C140 (2006) and IQS No. 1077/1987 (1987). Usually the buildings have a R.C lintel beam right above the window and door. The connection at the base of the walls is obtained through strip reinforced concrete footing with nonstepped stone or solid block work. Mechanical properties, such as the compressive strength of masonry units and mortar, were either evaluated by physical tests performed in construction laboratories in the region or selected from common features of masonry units. Due to the lack of experimental data, EC6 (CEN 2005) and the FEMA274 (1997) recommend a modulus of elasticity of $\mathrm{E}=1000 f_{k}$ and $E=550 f_{k}$, respectively, for masonry walls. In this study, the modulus of elasticity of masonry is assumed to be $\mathrm{E}=750 f_{k}$ (approximate mean values of the EC6 and FEMA 274 values); $f_{k}$ is the characteristic compressive strength of masonry (in $\mathrm{MPa}$ ) and can be calculated using the EC6 equation $f_{k}=k \times f_{b}^{0.65} \times f_{m}^{0.25}$, where $k$ is a constant value that ranges from 0.4 to 0.6 depending on the type of masonry and mortar and $f_{b}$ and $f_{m}$ are the compressive strengths of masonry units and mortar, respectively. The shear modulus $\mathrm{G}$ is $40 \%$ of the modulus of masonry E. To this end, the main values of the material properties of the masonry are taken as Young's modulus $\mathrm{E}=4,350 \mathrm{MPa}$, shear modulus $\mathrm{G}=1,740 \mathrm{MPa}$, and specific weight $=21 \mathrm{kN} / \mathrm{m}^{3}$. The numerical model was developed using the TREMURI code (Lagomarsino et al. 2006), which enables the representation of a complete three-dimensional (3D) model of URM structures using an effective macroelement approach, and demonstrates the nonlinear behavior of masonry panels and piers (see Figs. 5 and 6). Shear failure (sliding or diagonal cracking) and bending failure (tensile and compressive cracking), which are two common, in-plane damage failures of a masonry panel, are considered in the nonlinear macroelement model. The out-of-plane damage mechanism of a masonry wall is not considered, whereas the total behavior of a structure is considered. As opposed to finite element models, nonlinear 3D time-history analyses using TREMURI software can predict the seismic performance of URM buildings without a large computational load.

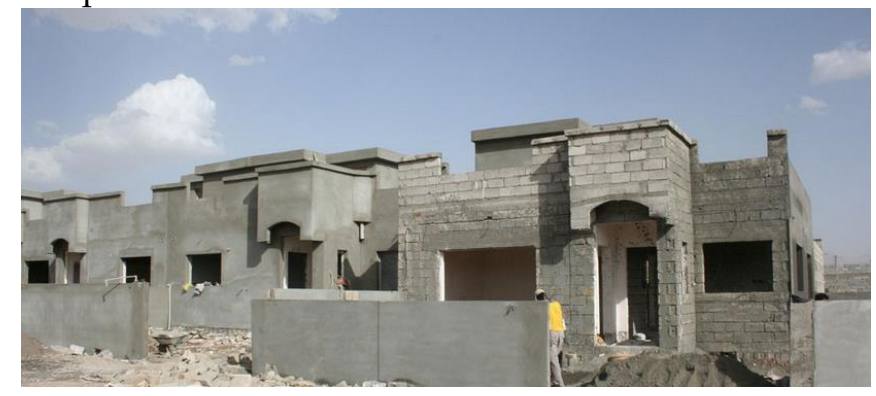

Fig (4) : An example of single-story URM buildings in the KR

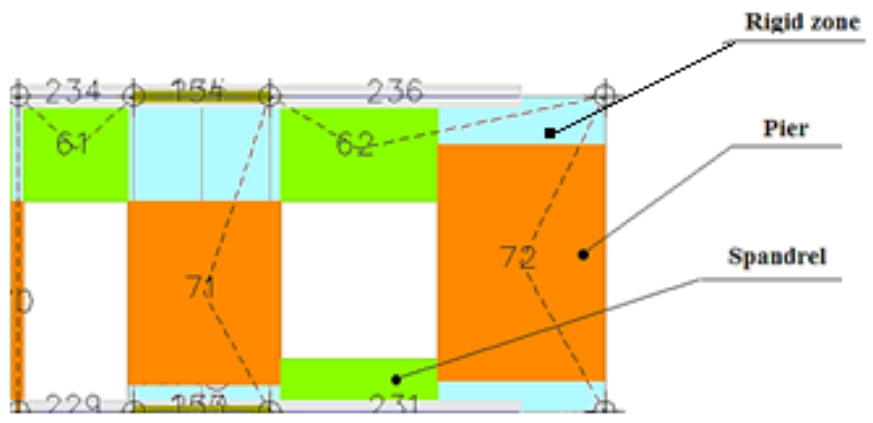

Fig (5) Macro-element modelling of a masonry panel used in the TREMURI software 


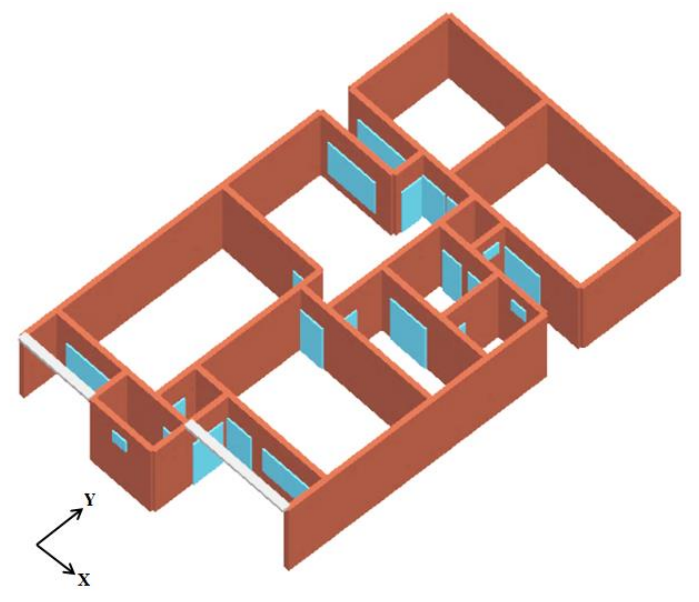

Fig (6) : 3D view of the single-story buildings modelled in the TREMURI software (research version).

\subsection{Damage States}

Defining an indicator to represent the level damage of a structure caused by an earthquake is another main step toward developing of fragility curves. Damage level (also known as performance level or limit state) is a limit or point which the structure can't carry the load and perform a desired function anymore. These limits and levels can be obtained through post-earthquake investigations while expressing these observation in verbal terms (qualitative manner) or mathematically by correlation between observed damage and system response parameter (Erbay , 2007). The latter (quantitative manner) is widely accepted since the former is only applicable to the similar building configuration and ground motion condition. A number of damage measures were proposed by researchers for buildings subject to earthquake loadings such as displacement-based measure (Rodriguez and Aristizabal, 1999), energy-based criteria (Wong and Wang, 2001), and hybrid measures (Rodriguez and Aristizabal, 1999; Park and Ang,1985). Damage levels or limit states are typically specified in terms of displacement-based measures by defining the drift values as system response parameter. Tomazevic (2007) reckoned that structural damage in masonry buildings is independent of type of the masonry and can be directly associated to story drift. Furthermore, these damage values can be easily evaluated without so much effort and many correlations between them and structural damage limit states are also available. On the other hand, as it can be seen from Table 2, a significant difference between threshold drift values proposed by several studies for a same class of structures (URM buildings) there exist due to utilizing different experimental results in each reference. Therefore, as Seyedi et al. (2010) indicated, those definitions and criteria which considered fixed drift ratios for a generic typology of buildings and not differ for specific cases may not be as accurate as those are defined based on the strength and the ductility of each model such as Milutinovic and Trendafiloski (2003). For that reason, based on the recommendation of Seyedi et al. (2010) and Gehl et al. (2013b), the Milutinovic and Trendafiloski (2003) criterion is used in this study. The performance levels (damage states) are classified into five states, i.e., slight, moderate, extensive, very heavy, and collapse, as shown in Table 3. The yield displacement (dy) and ultimate displacement $(\mathrm{du})$ values, which are required by this criterion, are obtained via pushover analysis of building using the TREMURI software.

TABLE (2) : Performance levels for URM buildings based on different studies

\begin{tabular}{|c|c|c|c|c|}
\hline \multirow{2}{*}{ Author } & & \multicolumn{3}{|l|}{ Drift ratio \% } \\
\hline & & Immediate & Life & Collapse \\
\hline & & & & \\
\hline \multirow{3}{*}{ HAZUS (NIBS, 1999) } & & & 0.0 & \\
\hline & $\begin{array}{l}\text { Low } \\
\text { code }\end{array}$ & 0.3 & $\begin{array}{l}0.6- \\
1.5\end{array}$ & 3.5 \\
\hline & $\begin{array}{l}\text { Pre } \\
\text { code }\end{array}$ & 0.2 & $\begin{array}{l}0.5- \\
1.2\end{array}$ & 2.8 \\
\hline Tomazevic (2007) & & $0.2-0.4$ & $\begin{array}{l}0.3- \\
0.6\end{array}$ & $1.0-2.0$ \\
\hline Erbay (2007) & & 0.1 & 0.6 & 1.0 \\
\hline Calvi (1999) & & 0.1 & 0.3 & 0.5 \\
\hline
\end{tabular}


TABLE (3) : Performance levels calculated for singlestory URM buildings in KR based on Milutinovic and Trendafiloski (2003) criterion

\begin{tabular}{lll}
\hline $\begin{array}{l}\text { Damage } \\
\text { state }\end{array}$ & $\begin{array}{l}\text { Limit-horizontal } \\
\text { displacement equation }\end{array}$ & $\begin{array}{l}\text { Drift } \\
\text { ratio } \\
\%\end{array}$ \\
\hline Slight & $\mathrm{d}=0.7 \mathrm{dy}$ & 0.017 \\
Moderate & $\mathrm{d}=0.7 \mathrm{dy}+0.05(0.9 \mathrm{du}-0.7 \mathrm{dy})$ & 0.045 \\
$\begin{array}{l}\text { Extensive } \\
\text { Very }\end{array}$ & $\mathrm{d}=0.7 \mathrm{dy}+0.2(0.9 \mathrm{du}-0.7 \mathrm{dy})$ & 0.127 \\
$\begin{array}{l}\text { heavy } \\
\text { Collapse }\end{array}$ & $\mathrm{d}=0.7 \mathrm{dy}+0.5(0.9 \mathrm{du}-0.7 \mathrm{dy})$ & 0.293 \\
\hline
\end{tabular}

\subsection{Analysis Method}

The greatest importance to achieve an effective strategy to prevention of at least reduction of disaster damage and achieving a satisfactory level is the understanding of the real structural behavior of building stock in the region. Incremental Dynamic Analysis (IDA) (Vamvatsikos and Cornell, 2002) is one of the accurate methods that can be used for that purpose. The IDA procedure is often described as a "dynamic" pushover procedure as it provides dynamic capacity curves for different ground motion levels. In IDA the ground motion time history is scaled to multiple levels of intensity and applied to the structure performing multiple nonlinear dynamic analyses of a structural model until the complete capacity curve is formed. The constructed capacity curve displays the entire range of structural behavior from elastic to inelastic and finally to global dynamic instability and collapse. As the available recorded natural time histories are not enough to cover all possible levels of intensity, scaling in terms of multiplying or dividing the acceleration time histories by a common factor as a solution for that issue is often used. However, from a seismological viewpoint, the simple scaling of time history is approximately equivalent to the change in the source-to-site distance and consequently the change of frequency content (Bommer and Acevedo, 2004). Nevertheless, studies such as Vamvatsikos and Cornell (2002) and Dhakal et al. (2007) indicted that based on the ground motion IM used in the scaling of time history, bias produced in the results differs. They showed that IMs such as peak ground acceleration (PGA) can be used in short period structures without producing a significant dispersion of response. Thus, PGA is used in this study to scale of time histories needed by IDA. Estimating the global dynamic capacity of the structure, better reading for the behavior change of structural response with increasing the ground motion intensity, and understanding the nature of structural response under the effect of more sever levels of ground motion are some of those advantages which are mentioned by Vamvatsikos and Cornell (2002) for IDA. Nevertheless, proper selection of the parameters for measuring the ground motion intensities in addition to using a large number of ground motions are some issues that should be considered when IDA is used as analysis method (Vilaverde, 2007). A thorough understanding of the local geological conditions, previous earthquakes and available seismological data of the area under study is therefore crucial to select a suitable set of ground motions.

\subsection{Seismic Hazard Characterization}

As mentioned above, proper selection of seismic inputs, which correspond to the seismic and site conditions of the area in which the structures are located, is of great importance for performing fragility analysis. Due to the increased acceptance of recorded time histories, which are available in online databases (e.g. PEER NGA (Chiou et al. 2008)), the use of natural earthquake records has become a prevalent research technique (Iervolino and Manfredi 2008). Furthermore, these types of records carry all the ground motion characteristics in addition to the features of geological and site conditions; because they are obtained from real events. Additionally, for nonlinear analysis purposes, the use of natural time histories was also suggested by several studies such as Idris (1991) and Hancock et al. (2006).

On the other hand, based on the purpose of seismic risk assessment, the number of natural records which are required as well as the parameters that are needed to be considered may vary. In the probabilistic structural assessment, which the purpose of ground motion selection is to achieve small computational effort to estimate the response correctly, the number of records and parameters may be extremely large (Iervolino and Manfredi, 2008). However, in the code-based design the records choose to match a previously defined design scenario and hence a smaller number of records are required. For instance, EC8 (CEN, 2003) specifies a set of three accelerograms as the minimum number required of records with considering the maximum effect of the records on structure. If the mean effect on the structure is of interest, at least seven records should be used for analysis of nonspatial structures and 14 records (representing the two horizontal components of the seismic action for seven records) for spatial structures ignoring the vertical component of the seismic action which is used only in special cases such as long span elements. Furthermore, the records should adequately represent the seismic and soil condition of the site. More recently, Gehl et al. (2013a) showed that "a relatively small error is introduced into the final results by the limited number of analyses usually used" in developing fragility curves using non-linear dynamic analysis method. Shome et al. (1998) showed that, for a mid-rise building, 10 to 20 records are sufficient to predict its seismic demand with an acceptable level of 
accuracy.

As there is a variety in the conclusions made by different studies mentioned in the literature, it was decided to select, as possible as, a relatively large number of records. To do that, ground motion intensity measure in a range the structure is sensitive to, can be used as mentioned by Iervolino \& Manfredi (2008), in addition to considering some other features such as earthquake magnitude, distance to source, or fault mechanism. This may also require a specific and sometimes a large amount of information about the hazard at the site. To this end and based on the seismic characteristics of KR obtained from Yaseen (2015), 59 real recordings from PEER NGA database (Chiou et al. 2008) (available at http://peer.berkeley.edu/assets/ NGA_Flatfile.xls ) are obtained and used in the study (see Table 4). The earthquake data was chosen from all over the world because local data is not available for the region.

\section{DEVELOPMENT OF FRAGILITY CURVES}

The statistical description of the building response can be obtained by using a log-normal distribution function as suggested by Cornell et al. (2002). Probability of exceeding the different damage states is then computed for the tested model using the distribution function. Graphically representation of this probability as function of a given ground motion intensity measure is known as fragility curve. Thus, the fragility curve in this study is presented in the form of a two parameter lognormal distribution function as follows.

$\mathrm{F}(\mathrm{X})=\mathrm{P}(\mathrm{d}>\mathrm{D})=\Phi\left[\frac{\ln (\mathrm{X})-\mu}{\sigma}\right]$

Where, $\Phi$ is the standard normal cumulative distribution function, $X$ is the distributed intensity measure (e.g., PGA), $D$ is the damage state, and $\mu$ and $\sigma$ are the median and standard deviation of the natural logarithm of the intensity measures, respectively. In the context of IDA and for the present study, these parameters $\mu$ and $\sigma$ can be estimated by taking logarithms of each PGA value associated with damage state (e.g. collapse) of a record.

TABLE (4) : Earthquake records selected for the study

\begin{tabular}{|c|c|c|c|c|}
\hline $\begin{array}{c}\text { NGA } \\
\text { record } \\
\text { No. }\end{array}$ & Earthquake name & Mag. & Distance $(\mathrm{km})$ & $\begin{array}{c}\text { PGA } \\
(\mathrm{g})\end{array}$ \\
\hline 126 & Gazli, USSR & 6.8 & 12.8 & 0.60 \\
\hline 139 & Tabas, Iran & 7.35 & 20.6 & 0.33 \\
\hline 143 & Tabas, Iran & 7.35 & 55.2 & 0.84 \\
\hline 169 & Imperial Valley-06 & 6.53 & 33.7 & 0.24 \\
\hline 174 & Imperial Valley-06 & 6.53 & 29.4 & 0.36 \\
\hline 178 & Imperial Valley-06 & 6.53 & 28.7 & 0.27 \\
\hline 179 & Imperial Valley-06 & 6.53 & 27.1 & 0.36 \\
\hline 180 & Imperial Valley-06 & 6.53 & 27.8 & 0.52 \\
\hline
\end{tabular}

\begin{tabular}{|c|c|c|c|c|}
\hline 181 & Imperial Valley-06 & 6.53 & 27.5 & 0.41 \\
\hline 182 & Imperial Valley-06 & 6.53 & 27.6 & 0.46 \\
\hline 183 & Imperial Valley-06 & 6.53 & 28.1 & 0.60 \\
\hline 184 & Imperial Valley-06 & 6.53 & 27.2 & 0.35 \\
\hline 568 & San Salvador & 5.8 & 7.9 & 0.88 \\
\hline 723 & Superstition Hills- & 6.54 & 16.0 & 0.46 \\
\hline 729 & Superstition Hills- & 6.54 & 29.4 & 0.18 \\
\hline 779 & Loma Prieta & 6.93 & 18.5 & 0.97 \\
\hline 802 & Loma Prieta & 6.93 & 27.2 & 0.51 \\
\hline 803 & Loma Prieta & 6.93 & 27.1 & 0.25 \\
\hline 821 & Erzican, Turkey & 6.69 & 9.0 & 0.50 \\
\hline 825 & Cape Mendocino & 7.01 & 10.4 & 1.50 \\
\hline 828 & Cape Mendocino & 7.01 & 4.5 & 0.59 \\
\hline 879 & Landers & 7.28 & 44.0 & 0.72 \\
\hline 953 & Northridge-01 & 6.69 & 13.4 & 0.42 \\
\hline 959 & Northridge-01 & 6.69 & 4.9 & 0.36 \\
\hline 963 & Northridge-01 & 6.69 & 40.7 & 0.57 \\
\hline 983 & Northridge-01 & 6.69 & 13.0 & 0.57 \\
\hline 1004 & Northridge-01 & 6.69 & 8.5 & 0.75 \\
\hline 1013 & Northridge-01 & 6.69 & 11.8 & 0.51 \\
\hline 1044 & Northridge-01 & 6.69 & 20.3 & 0.58 \\
\hline 1048 & Northridge-01 & 6.69 & 3.4 & 0.37 \\
\hline
\end{tabular}

Table (4) : Continued...

\begin{tabular}{|c|c|c|c|c|}
\hline $\begin{array}{c}\text { NGA } \\
\text { record } \\
\text { No. }\end{array}$ & Earthquake name & Mag. & Distance $(\mathrm{km})$ & $\begin{array}{c}\text { PGA } \\
(\mathrm{g})\end{array}$ \\
\hline 1085 & Northridge-01 & 6.69 & 13.6 & 0.83 \\
\hline 1086 & Northridge-01 & 6.69 & 16.8 & 0.60 \\
\hline 1111 & Kobe, Japan & 6.9 & 8.7 & 0.51 \\
\hline 1119 & Kobe, Japan & 6.9 & 38.6 & 0.69 \\
\hline 1148 & Kocaeli, Turkey & 7.51 & 53.7 & 0.22 \\
\hline 1197 & Chi-Chi, Taiwan & 7.62 & 32.7 & 0.65 \\
\hline 1231 & Chi-Chi, Taiwan & 7.62 & 31.7 & 0.97 \\
\hline 1244 & Chi-Chi, Taiwan & 7.62 & 32.0 & 0.35 \\
\hline 1402 & Chi-Chi, Taiwan & 7.62 & 88.8 & 0.31 \\
\hline 1485 & Chi-Chi, Taiwan & 7.62 & 77.5 & 0.47 \\
\hline 1489 & Chi-Chi, Taiwan & 7.62 & 38.9 & 0.29 \\
\hline 1492 & Chi-Chi, Taiwan & 7.62 & 39.6 & 0.35 \\
\hline 1503 & Chi-Chi, Taiwan & 7.62 & 26.7 & 0.81 \\
\hline 1504 & Chi-Chi, Taiwan & 7.62 & 28.7 & 0.50 \\
\hline 1505 & Chi-Chi, Taiwan & 7.62 & 47.9 & 0.57 \\
\hline 1507 & Chi-Chi, Taiwan & 7.62 & 15.4 & 0.57 \\
\hline 1508 & Chi-Chi, Taiwan & 7.62 & 21.4 & 0.49 \\
\hline 1509 & Chi-Chi, Taiwan & 7.62 & 19.1 & 0.60 \\
\hline
\end{tabular}




\begin{tabular}{|c|c|c|c|c|}
\hline 1510 & Chi-Chi, Taiwan & 7.62 & 20.7 & 0.33 \\
\hline 1511 & Chi-Chi, Taiwan & 7.62 & 16.0 & 0.30 \\
\hline 1512 & Chi-Chi, Taiwan & 7.62 & 5.0 & 0.44 \\
\hline 1513 & Chi-Chi, Taiwan & 7.62 & 7.6 & 0.74 \\
\hline 1517 & Chi-Chi, Taiwan & 7.62 & 8.9 & 1.16 \\
\hline 1524 & Chi-Chi, Taiwan & 7.62 & 95.7 & 0.38 \\
\hline 1549 & Chi-Chi, Taiwan & 7.62 & 14.2 & 1.00 \\
\hline 1596 & Chi-Chi, Taiwan & 7.62 & 14.2 & 0.96 \\
\hline 1602 & Duzce, Turkey & 7.14 & 41.3 & 0.73 \\
\hline 1605 & Duzce, Turkey & 7.14 & 1.6 & 0.35 \\
\hline 1633 & Manjil, Iran & 7.37 & 40.4 & 0.51 \\
\hline
\end{tabular}

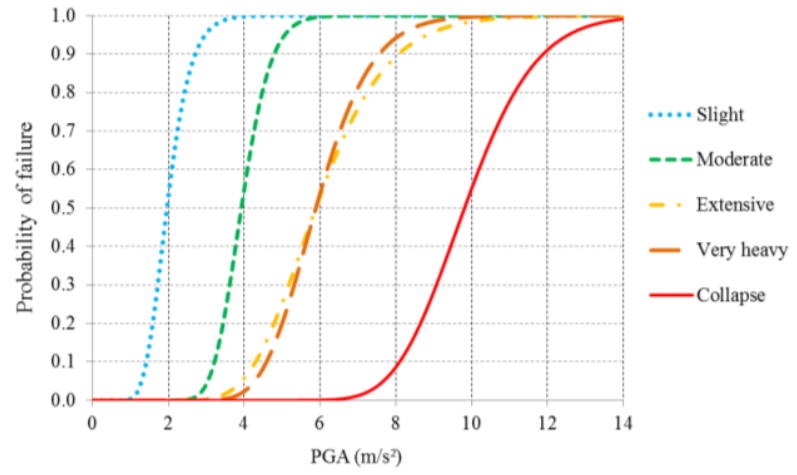

Fig (7) : Fragility curves for the five performance levels, URM single-story building

The IDA method is therefore applied to develop the fragility curves for the tested building. Overall, 470 time-history analyses have been carried out on an analytical model using the TREMURI software. Each of the 59 ground motions presented previously is scaled to eight levels of intensity according to its peak ground acceleration value (e.g. $0.025 \mathrm{~g}, 0.05 \mathrm{~g}, 0.1 \mathrm{~g}, 0.2 \mathrm{~g}, 0.4 \mathrm{~g}$, $0.6 \mathrm{~g}, 0.8 \mathrm{~g}$, and $1.0 \mathrm{~g}$ of PGA ) in X-direction (i.e. shorter direction of building) and the nonlinear dynamic analyses are carried out at each level of intensity. The results are then used to produce the building's fragility curves for each limit state using Eq. 1 by calculating the median and the standard deviation of the logarithmic values of the PGA at each performance level, using the Milutinovic and Trendafiloski (2003) criterion (i.e. slight, moderate, extensive, very heavy, and collapse) shown in Table 3. PGA is used here because several studies, as mentioned before, showed that the PGA can be used for short period structures without producing a significant dispersion of response. Furthermore, it can be easily derived from direct measurements or simple mathematical models besides it's widely use in most of the available seismic hazard maps. The PGA based fragility curves are shown in Fig. 7. Based on the results obtained it can be concluded that the single-story URM buildings in the KR are highly susceptible to slight damage under seismic loads. Moderate damage can be occurred to those buildings that are located in zones with PGA greater than $0.3 \mathrm{~g}$. Although collapse failure are not expected to be occur in the considered buildings for a range of PGA specified to the KR, the buildings, however, may face to the extensive and very heavy damage, particularly in the east part of the KR that has a PGA greater than $0.4 \mathrm{~g}$.

\section{CONCLUSIONS}

The present study investigates the seismic safety of common unreinforced masonry low-rise (single-story) buildings in Kurdistan region of Iraq, using analytical fragility analysis approach. Incremental dynamic analysis was used to develop the fragility curves using time histories of 59 different earthquake data. The fragility curves associated to five damage states slight, moderate, extensive, very heavy, and collapse indicated that masonry buildings are highly susceptible to slight and moderate damages under seismic loads. Furthermore, extensive to very heavy damage can be caused to the URM single-story buildings in the eastern part of the KR. Hence, seismic safety of the investigated low-rise buildings is questionable. A detailed seismic safety assessment for all unreinforced masonry low-rise building types in the region is therefore very important. Definition of strengthening of unreinforced masonry buildings via simplified and fast methodologies, is also could be the next important step that should be taken towards the eliminating of the loss of the lives and reducing the economic impact of the earthquakes in the future.

\section{ACKNOWLEDGMENT}

The authors are grateful to the TREMURI staff for providing the academic and commercial versions of the TREMURI software, which were used in the example analyses.

\section{REFERENCES}

1. Ameer, A. S., Sharma, M. L., Wason, H. R. and Alsinawi, S. A. (2005), "Probabilistic seismic hazard assessment for Iraq using complete earthquake catalogue files", pure and applied geophysics, 162(5), 951-966.

2. American Society of Civil Engineers (ASCE). (2000), Prestandard and commentary for the seismic rehabilitation of buildings", FEMA-356, Washington, D.C.

3. ASTM C140 (2006), Standard test methods for sampling and testing concrete masonry units and related units, American Society for Testing and Materials International, West Conshohocken. 
4. ATC (1985), Earthquake damage evaluation data for California, Applied Technology Council, California.

5. Bommer, J. J. and Acevedo, A. B. (2004), "The use of real earthquake accelerograms as input to dynamic analysis", Journal of Earthquake Engineering, 8(S1), 4391.

6. BRC (1997), Iraqi seismic code requirements for buildings 2/97, Building Research Centre, Baghdad.

Calvi, G. M. (1999), "A displacement-based approach for vulnerability evaluation of classes of buildings", Journal of Earthquake Engineering, 3(3), 411-438.

7. Calvi, G. M., Pinho, R., Magenes, G., Bommer, J. J., Restrepo-Vélez, L. F. and Crowley, H. (2006), "Development of seismic vulnerability assessment methodologies over the past 30 years", ISET Journal of Earthquake Technology, 43(3), 75-104.

8. CEN (2003), Eurocode 8 - Design of Structures for Earthquake Resistance, Part 1: General rules, sesmic action, and rules for buildings (Report), European Union, European Committee for Standardization, Brussels.

9. CEN (2005), Eurocode 6 - Design of masonry structures - part 1-1: General rules for reinforced and unreinforced masonry structures (Report), European Union, European Committee for Standardization, Brussels.

10. Central Statistical Organization (2011), Buildings, dwelling and establishment census and households listing, Enumeration and listing report (Report no. 1, buildings, dwelling and households- national level), CSO, Baghdad.

11. Chiou, B., Darragh, R., Gregor, N. and Silva, W. (2008), "NGA project strong-motion database" Earthquake Spectra, 24(1), 23-44.

12. Coburn, A. and Spence, R. (2002), Earthquake Protection, (2nd Edition), Wiley, West Sussex, UK.

13. Cornell, C., Jalayer, F., Hamburger, R. and Foutch, D. (2002), "Probabilistic basis for 2000 SAC federal emergency management agency steel moment frame guidelines", Journal of Structural Engineering, 128(4), 526-533.

14. Dhakal, R. P., Singh, S. and Mander, J. B. (2007), "Effectiveness of earthquake selection and scaling method in New Zealand", Bulletin of the New Zealand Society for Earthquake Engineering, 40(3), 160-171.

15. Erbay, O. O. (2007), A methodology to assess seismic risk for populations of unreinforced masonry buildings (Report 07-10), Mid-America Earthquake Center, Urbana.

16. FEMA (1999), HAZUS99 user and technical manuals (Report: HAZUS 1999), Federal Emergency Management Agency, Washington, D.C.

17. FEMA (2003), HAZUS-MH MR3 technical manual, Department of Homeland Security, Emergency Preparedness and Response Directorate, Federal
Emergency Management Agency, Washington, D.C. 18. FEMA 274-ASCE (1997), FEMA 274-NEHRP commentary on the NEHRP guidelines for the seismic rehabilitation of buildings, Federal Emergency Management Agency-ASCE, Washington, D.C.

19. Gehl, P., Douglas, J. and Seyedi, D. (2013a), "Influence of the number of dynamic analyses on the accuracy of structural response estimates", Earthq Spectra, doi: 10.1193/102912eqs320m.

20. Gehl, P., Seyedi, D. M. and Douglas, J. (2013b), "Vector-valued fragility functions for seismic risk evaluation", Bulletin of Earthquake Engineering, 11(2), 365-384.

21. Grünthal, G. (Editor). (1998), European Macroseismic Scale 1998 (EMS-98), Cahiers du Centre Européen de Géodynamique et de Se'ismologie, 15, Luxembourg.

22. Hancock, J., Watson-Lamprey, J., Abrahamson, N., BOMMER*, J., Markatis, A., McCOYH, E. and Mendis, R. (2006), "An improved method of matching response spectra of recorded earthquake ground motion using wavelets", Journal of Earthquake Engineering, 10(S1), 67-89.

23. Idriss, I. M. (1991), Selection of earthquake ground motions at rock sites, Report prepared for the Structures Division, Building and Fire Re-search Laboratory, NIST. 24. Iervolino, I. and Manfredi, G. (2008), "A review of ground motion record selection strategies for dynamic structural analysis", Modern Testing Techniques for Structural Systems, Springer, Vienna, 131-163.

25. IQS No. 1077/1987 (1987), Load-bearing concrete masonry units, Iraqi specifications, Baghdad.

26. Lagomarsino, S., Penna, A. and Galasco, A. (2006), "TREMURI program: Seismic analysis program for 3D masonry buildings", University of Genoa, Available at: http:/ /www.stadata.com/ (accessed 20 May 2013).

27. Liao, W. I., Loh, C. H. and Tsai, K. C. (2006), "Study on the fragility of building structures in Taiwan" Natural hazards, 37(1-2), 55-69.

28. Milutinovic, Z. and Trendafiloski, G. (2003), WP4 Vulnerability of current buildings, Risk-UE: An advanced approach to earthquake risk scenarios with applications to different European towns, European Commission, Contract No. EVK4-CT-2000-00014.

29. NIBS (1999), HAZUS 99 earthquake loss estimation methodology (Technical manual), National Institute of Building Science, Washington, D.C.

30. Nielson, B. G. and DesRoches, R. (2007), "Seismic fragility methodology for highway bridges using a component level approach", Earthquake Engineering \& Structural Dynamics, 36(6), 823-839.

31. Park, J., Powashiraporn, P., Craig, J. I. and Goodno, B. J. (2009), "Seismic fragility analysis of low-rise unreinforced masonry structures", Engineering Structures, 31(1), 125-137. 
32. Park, Y. J. and Ang, A. H. S. (1985), "Mechanistic seismic damage model for reinforced concrete", Journal of Structural Engineering, 111(4), 722-739.

33. Porter, K. (2003), Seismic vulnerability, in W. F. Chen and C. Scawthorn (Editors), Earthquake Engineering Handbook, CRC Press, Boca Raton, USA.

34. Rodriguez, M. E. and Aristizabal, J. C. (1999), "Evaluation of a seismic damage parameter", Earthquake engineering \& structural dynamics, 28(5), 463-477.

35. Rossetto, T. and Elnashai, A. (2003), "Derivation of vulnerability functions for european-type rc structures based on observational data", Engineering Structures, 25(10), 1241-1263.

36. Seyedi, D. M., Gehl, P., Douglas, J., Davenne, L., Mezher, N. and Ghavamian, S. (2010), “Development of seismic fragility surfaces for reinforced concrete buildings by means of nonlinear time-history analysis", Earthquake Engineering \& Structural Dynamics, 39(1), 91-108.
37. Shome, N., Cornell, C. A., Bazzurro, P. and Carballo, J. E. (1998), "Earthquakes, records, and nonlinear responses", Earthquake Spectra, 14(3), 469-500.

38. Tomazevic, M. (2007), "Damage as a measure for earthquake resistant design of masonry structures: Slovenian experience," Canadian Journal of Civil Engineering, 34(11), 1403-1412.

39. Vamvatsikos, D. and Cornell, C. (2002), "Incremental dynamic analysis", Earthquake Engineering \& Structural Dynamics, 31(3), 491-514.

40. Villaverde, R. (2007), "Methods to assess the seismic collapse capacity of building structures: State of the art", Journal of Structural Engineering, 133(1), 57-66.

41. Wong, K. K. and Wang, Y. (2001), "Energy-based damage assessment on structures during earthquakes", The Structural Design of Tall Buildings, 10(2), 135-154.

42. Yaseen, A. A. (2015), Seismic fragility assessment of masonry buildings in the Kurdistan region(Doctoral Thesis).University of Portsmouth, Portsmouth, UK. 